\title{
Granitoid rocks and associated coper skarn, Whycocomagh Mountain, Cape Breton Island, Nova Scotia
}

\author{
S.M. Barr, R. Yip Choy, 2.A. Colwell and H.S. Oldale \\ Department of Geology. Acadia University, Wolfville, N.S. BOP exO
}

\begin{abstract}
Mineralized (Fe-Cu-W-Mo) skarn in the Whycocomagh Mountain area is associated with a small pluton of Devonian $(402 \pm 20 \mathrm{Ma})$ age, which intruded predominantly metasedimentary rocks of the Hadrynian George River Group. The pluton consists largely. of granite porphyry with a marginal granodiorite to diorite zone, and minor porphyritic granodiorite to monzodiorite dykes and pegmatite. The suite is calc-alkalic with I-type characteristics. Although weakly mineralized, the Whycocomagh Mountain pluton has features typical of plutons associated with porphyry-type Cu-Mo deposits. Calc-silicate rocks derived from marbles of the George River Group are the chief hosts for magnetite \pm chalcopyrite \pm scheelite \pm molybdenite alteration envelopes. Characteristics of the pluton and the skarn minerals suggest that the deposit is a copper skarn.

Un skarn mineralisé ( $\mathrm{Fe}-\mathrm{Cu}-\mathrm{W}-\mathrm{Mo}$ ), situe dans la région de la montagne Whycocomagh, est associé à une petite intrusion ignée d'age Dévonien $(402 \pm 20$ m.a.) qui pénètre des roches, principalement des métasédiments, du groupe George River (Hadrynien). Le pluton consiste surtout en un granite porphyrique accompagné d'une zone marginale (granodiorite à diorite), de dykes mineurs (granodiorite à monzodiorite porphyrique) et de pegmatite. L'ensemble est calco-alcalin et de "type I". Bien que faiblement minéralisé, le pluton Whycocomagh Mountain possède les caractéristiques typiques des plutons associés aux dépôts porphyriques de type $\mathrm{Cu}-\mathrm{Mo}$. Les calco-silicates dérivés des marbres du groupe George River sont les hôtes principaux du cortège magnétite \pm chalcopyrite \pm scheelite \pm molybdenite \pm pyrite que l'on retrouve dans des veinules le long des fractures et disséminés dans les enveloppes d'altération voisines. Les caractéristiques du pluton ainsi que la minéralogie du skarn font croire qu'il s'agit d'un dépôt de skarn cuprifère.
\end{abstract}

[Traduit par le journal]

\section{INTRODUCTION}

Copper, tungsten, and molybdenum occur in skarns and associated granitoid intrusive rocks on Whycocomagh Mountain in west-central Cape Breton Island (Fig. 1). The skarns have been described previously by Chatterjee in Milligan (1970), Chatterjee $(1977,1980)$, Chatterjee et al. (1980), and Black (1978, 1982) but the granitoid rocks have received little attention. Hence, the main purpose of this report is to discuss the petrography, geochemistry, and age of the granitoid rocks. In addition, further interpretations of the associated skarns are presented within the framework of current models for skarn development.

\section{GEOLOGICAL SETTING}

The Whycocomagh Mountain pluton as here defined is a small granitoid stock elongate in an east-west direction (Fig. 1,2), with associated porphyritic and pegmatoid dykes. It intruded predominantly metasedimentary rocks of the Late Hadrynian George River Group (Milligan 1970, Keppie 1979). Other granitoid rocks also occur in the Whycocomagh Mountain area, forming a long narrow body extending from near Lake Ainslie in the north along the eastern side of the mountain (Fig. 1). These latter rocks were mapped and sampled to a limited extent during the present study, and appear to be an older intrusive suite not directly related to the Whycocomagh Mountain pluton (Yip Choy 1982). Devono-Carboniferous sedimentary rocks of the Horton Group unconformably overlie all of these rock units (Kelley 1967).

\section{WHYCOCOMAGH MOUNTAIN PLUTON AND ASSOCIATED DYKES}

\section{Field Relations and Petrography}

Granite Porphyry

The Whycocomagh Mountain pluton consists predominantly of granite porphyry. Colour ranges from grey to pink to red, depending on the extent of hematitic alteration and mafic mineral content. Texture and grain size are also widely variable: dykes in the country rock are hiatal porphyritic, with a finegrained groundmass, whereas in the main pluton the rock does not generally appear distinctly porphyritic in hand specimen because the texture is seriate 


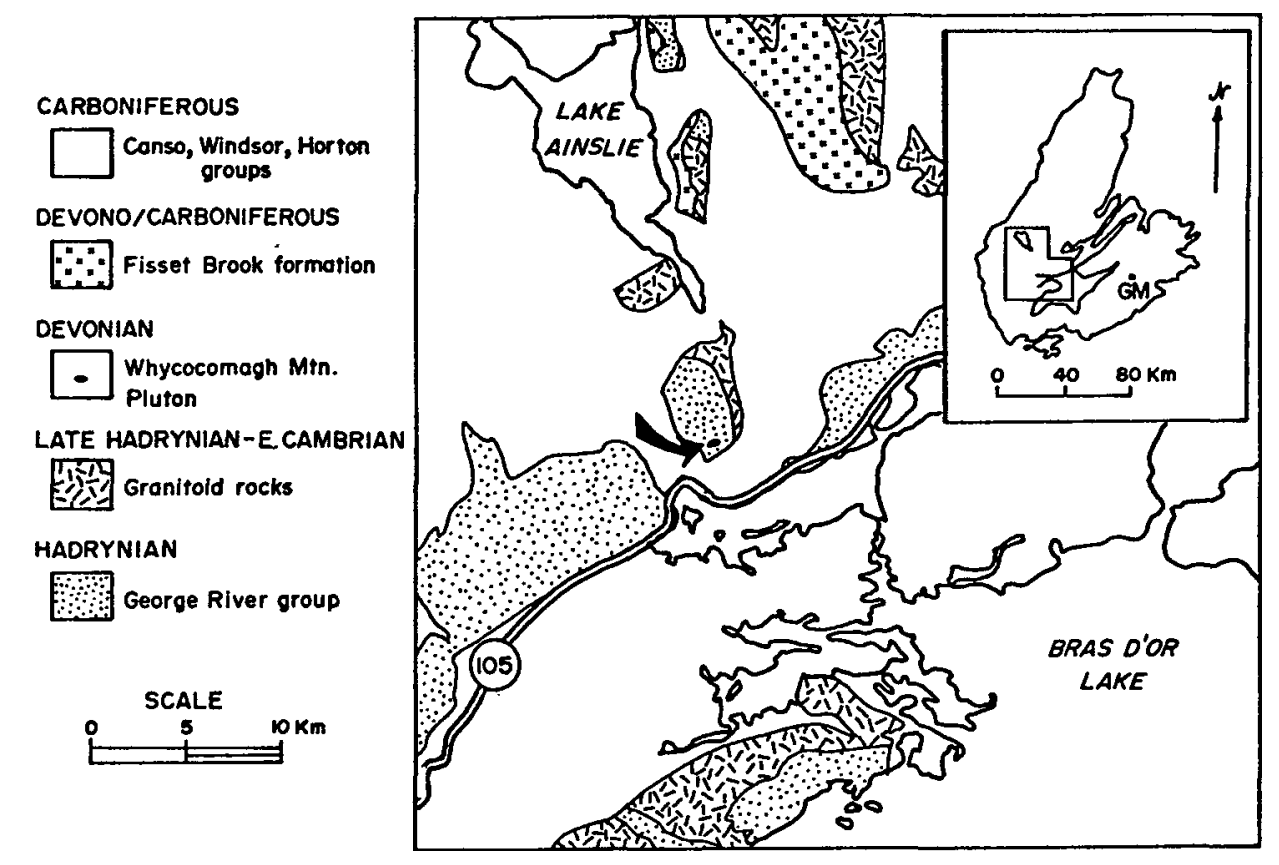

Fig. 1 - Regional geology of west-central Cape Breton Island (after Keppie 1979) showing the location of the Whycocomagh Mountain pluton (arrow). GM on inset map indicates the location of the Gillis Mountain pluton referred to in the text.

porphyritic and also tends to be masked by alteration. However, in thin section or on surfaces stained for potassium feldspar (method of Hutchison 1973), the porphyritic character is obvious, with phenocrysts up to $8 \mathrm{~mm}$ in length.

Phenocrysts generally form $40-50 \%$ of the rock. They are mainly subhedral plagioclase of andesine composition exhibiting a moderate degree of zoning, together with smaller and less abundant actinolitic hornblende crystals. Scattered rounded quartz and rare potassium feldspar phenocrysts are also present. The fine- to medium-grained groundmass consists largely of quartz and potassium feldspar, with minor plagioclase, amphibole, and biotite.

Potassium feldspars are generally too fine-grained for optical determinations but where possible, they yield a $2 \mathrm{~V}$ of $20-35^{\circ}$, indicating that they may be at least transitional to high temperature structural state (sanidine) (Shelley 1975, p. 184). Accessory minerals include magnetite, apatite, and sphene, as well as sulphides (pyrite, chalcopyrite, molybdenite) in some samples. Pervasive alteration varies from moderate to in- tense and includes saussurite (in plagioclase), sericite (in both plagioclase and alkali feldspar), chlorite (in biotite and amphibole) and hematite.

Accurate modal analyses are difficult because of grain size variations, but most of the samples are granites, transitional to granodiorites, following the classification of Streckeisen (1976). This is consistent with normative mineralogies of nine analyzed samples (seven from the main body and two from dykes; Table 1) which also range from granite to granodiorite (Fig. 3). These samples contain between 60 and $68 \%$ $\mathrm{SiO}_{2}$ but cluster near $66 \%$ (Table l; Fig. 4), a generally accepted boundary between intermediate (granodioritic) and felsic (granitic) rocks. As the majority of samples plot in the granite field in both modal and normative mineralogy, the unit is referred to as granite porphyry.

Other chemical features of the rocks are discussed in a subsequent section.

\section{Granodiorite-Diorite-Endoskarn}

Along the southeastern margin of the granite porphyry a zone of varied 
granitoid rocks has been outlined in trenches and drill holes (Fig. 2). These rocks appear to grade from typical granite porphyry through granodiorite to diorite, with progressive decrease in quartz and potassium feldspar content, loss of porphyritic texture, and increase in mafic mineral abundance, especially hornblende but locally biotite. Alteration is similar to that in the granite porphyry but generally more intense. The origin of these rocks is not clear. They may represent older dioritic rocks intruded and altered by the granite porphyry magma or they could represent part of the granite porphyry variably affected by desilication and alteration. A third possibility is that they are a younger intrusive unit of more mafic composition. Their chemical similarity (discussed in a subsequent section) to the granodioritemonzodiorite dykes described below suggests that the latter is the most likely explanation.

Locally within this area, clinopyroxene-bearing granitoid rocks were sampled. Their distribution and extent are not known because of limited exposure. They may represent an endoskarn (Einaudi et al. 1981) and consist of potassium feldspar (50-60\%), highly altered plagioclase $(20-40 \%)$, and diopside $\left(\mathrm{Di}_{8}\right.$ o $\left.\mathrm{Hd}_{1} 9 \mathrm{JO}_{1} ; 10-15 \%\right)$ with minor hornblende. Apatite and especially sphene are abundant accessory minerals. In terms of both modal and normative mineralogy the rocks are monzonites (Fig. 3).

\section{Granodiorite-Monzodiorite dykes}

Numerous dykes ranging in composition from granodiorite to monzodiorite have intruded both the granite porphyry and the country rocks (Fig. 2). They range from about $\mathrm{lm}$ to several meters in width, and are generally grey or pinkish grey in colour. They consist of scattered phenocrysts of plagioclase in a fine-grained groundmass of plagioclase, potassium feldspar, quartz, and amphibole. Accessory minerals include sphene, apatite, and opaques. Alteration is intense, with abundant chlorite and sericite, and quartz and calcite veining is very common. In the area

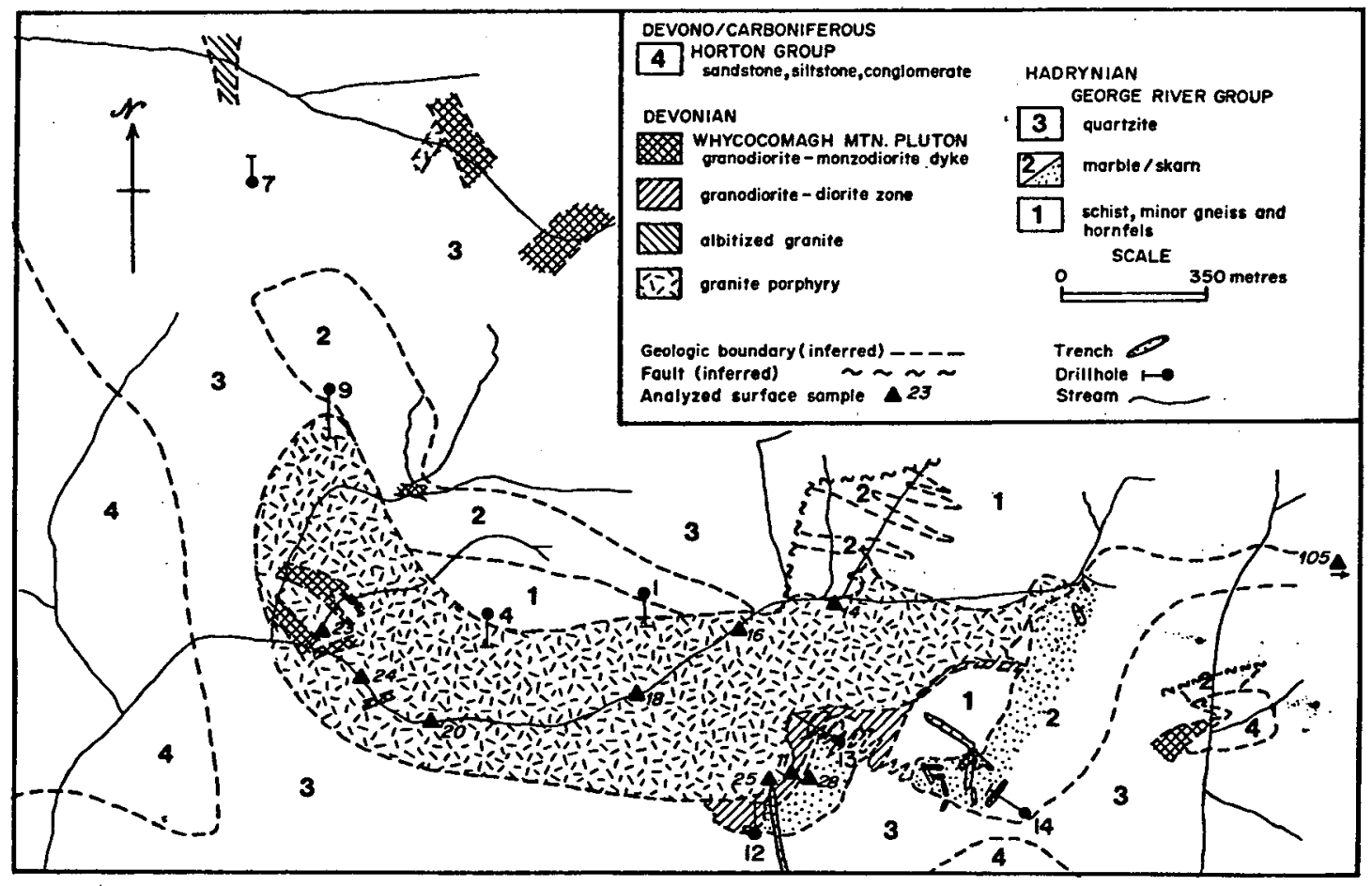

Fig. 2 - Geological map of the Whycocomagh Mountain pluton and adjacent rocks, simplified from an unpublished map compiled by D. Black of M.E.X. Explorations Limited. Locations of drill holes sampled for chemical analysis are shown (WM-1,4,7,9,12,13,14). 
Table 1

GEOCHEMICAL DATA', WHYCOCOMAGH MOUNTAIN PLUTON ${ }^{2}$

\begin{tabular}{|c|c|c|c|c|c|c|c|c|c|c|c|c|c|c|c|c|c|c|c|}
\hline \multirow[b]{2}{*}{$\begin{array}{l}\mathrm{SiO}_{2} \\
\mathrm{TiO}_{2} \\
\mathrm{Al}_{2} \mathrm{O}_{3} \\
\mathrm{Fe}_{2} \mathrm{O}_{3} * \\
\mathrm{MnO} \mathrm{MgO}^{2} \\
\mathrm{CaO} \\
\mathrm{Na}_{2} \mathrm{O} \\
\mathrm{K}_{2} \mathrm{O} \\
\mathrm{P}_{2} \mathrm{O}_{5} \\
\mathrm{LOI}\end{array}$} & \multicolumn{7}{|c|}{ Granite Porphyry } & \multicolumn{2}{|c|}{$\begin{array}{c}\text { O } \\
\text { Granite Porphyry } \\
\text { Dykes }\end{array}$} & \multicolumn{5}{|c|}{$\underset{\text { Granodiori te-Monzodiorite }}{X}$} & $\begin{array}{c}+ \\
\text { Endoskarn } \\
\text { WYRII } \\
\end{array}$ & \multicolumn{4}{|c|}{ Granodiorite-Monzodiorite } \\
\hline & $\begin{array}{c}64.3 \\
0.35 \\
15.4 \\
3.8 \\
0.06 \\
3.2 \\
1.7 \\
3.8 \\
4.1 \\
0.15 \\
2.7\end{array}$ & $\begin{array}{c}68.0 \\
0.30 \\
14.4 \\
2.9 \\
0.06 \\
1.9 \\
2.0 \\
3.6 \\
4.6 \\
0.10 \\
1.5\end{array}$ & $\begin{array}{c}64.9 \\
0.77 \\
14.8 \\
4.4 \\
0.10 \\
3.2 \\
2.9 \\
3.7 \\
3.5 \\
0.10 \\
1.5\end{array}$ & $\begin{array}{c}60.0 \\
0.85 \\
14.9 \\
7.7 \\
0.19 \\
4.0 \\
4.5 \\
3.0 \\
2.8 \\
0.14 \\
1.9\end{array}$ & \begin{tabular}{|c|} 
WYR28 \\
65.6 \\
0.50 \\
14.3 \\
3.6 \\
0.80 \\
2.2 \\
3.0 \\
3.4 \\
4.1 \\
0.12 \\
3.0
\end{tabular} & $\begin{array}{l}\text { WM } 1 \\
195 \\
65.9 \\
0.52 \\
14.7 \\
3.1 \\
0.06 \\
2.3 \\
2.8 \\
3.3 \\
3.9 \\
0.15 \\
2.4\end{array}$ & $\begin{array}{c}M M 9 \\
315 \\
66.2 \\
0.59 \\
13.6 \\
3.0 \\
0.05 \\
2.6 \\
2.9 \\
3.3 \\
4.0 \\
0.17 \\
3.1\end{array}$ & $\begin{array}{c}\text { WYR105 } \\
64.0 \\
0.30 \\
15.4 \\
4.1 \\
0.06 \\
2.4 \\
3.9 \\
4.3 \\
2.6 \\
0.16 \\
1.1\end{array}$ & $\begin{array}{c}M 7 \\
24 \\
66.3 \\
0.53 \\
15.8 \\
3.7 \\
0.06 \\
2.5 \\
2.9 \\
3.4 \\
3.4 \\
0.13 \\
1.8\end{array}$ & $\begin{array}{l}53.0 \\
0.70 \\
19.1 \\
7.4 \\
0.11 \\
4.3 \\
5.1 \\
5.0 \\
2.4 \\
0.28 \\
2.0\end{array}$ & $\begin{array}{c}\text { WM } 4 \\
90 \\
63.0 \\
0.60 \\
14.4 \\
4.8 \\
0.06 \\
3.2 \\
3.5 \\
2.5 \\
3.1 \\
0.21 \\
3.9\end{array}$ & $\begin{array}{c}\text { Wh } 12 \\
80 \\
60.8 \\
0.66 \\
16.2 \\
4.7 \\
0.07 \\
2.9 \\
4.3 \\
3.9 \\
3.6 \\
0.20 \\
2.9\end{array}$ & $\begin{array}{l}\text { WM } 13 \\
242 \\
53.3 \\
1.00 \\
18.1 \\
6.8 \\
0.13 \\
5.3 \\
7.3 \\
4.3 \\
2.4 \\
0.29 \\
2.2\end{array}$ & $\begin{array}{l}\text { WM } 13 \\
360 \\
59.6 \\
0.75 \\
16.1 \\
6.5 \\
0.15 \\
3.4 \\
5.1 \\
3.6 \\
2.7 \\
0.26 \\
3.0\end{array}$ & $\begin{array}{c}\text { WYR11 } \\
58.5 \\
0.50 \\
17.4 \\
2.4 \\
0.08 \\
4.1 \\
5.6 \\
3.5 \\
7.4 \\
0.20 \\
1.2\end{array}$ & $\begin{array}{c}5.3 \\
0.40 \\
16.2 \\
5.5 \\
0.09 \\
5.0 \\
3.7 \\
4.1 \\
3.4 \\
0.24 \\
4.4\end{array}$ & $\begin{array}{c}59.9 \\
0.40 \\
15.7 \\
4.7 \\
0.07 \\
3.5 \\
3.4 \\
3.9 \\
3.1 \\
0.19 \\
3.3\end{array}$ & $\begin{array}{c}M 9 \\
351 \\
59.4 \\
0.47 \\
15.2 \\
5.8 \\
0.04 \\
1.8 \\
5.4 \\
2.3 \\
3.8 \\
0.21 \\
5.4\end{array}$ & $\begin{array}{c}\text { WM } 14 \\
253 \\
57.4 \\
0.85 \\
16.5 \\
5.1 \\
0.13 \\
4.8 \\
4.0 \\
3.4 \\
4.0 \\
0.23 \\
4.4\end{array}$ \\
\hline Total & 99.6 & 99.4 & 99.9 & 100.0 & 99.8 & 99.1 & 99.5 & 98.3 & 100.5 & 99.4 & 99.3 & 100.2 & 100.9 & 101.0 & 100.9 & 98.3 & 98.2 & 99.6 & 99.7 \\
\hline $\begin{array}{l}\text { B } \\
\mathrm{Ba} \\
\mathrm{Cu} \\
\mathrm{F} \\
\mathrm{li} \\
\mathrm{Mo} \\
\mathrm{Pb} \\
\mathrm{Rb} \\
\mathrm{Sn} \\
\mathrm{Sr} \\
\mathrm{Th} \\
\mathrm{U} \\
\mathrm{Zn}\end{array}$ & $\begin{array}{r}6 \\
860 \\
19 \\
500 \\
30 \\
9 \\
3 \\
164 \\
1.9 \\
375 \\
19 \\
3.4 \\
31\end{array}$ & $\begin{array}{c}10 \\
520 \\
3 \\
400 \\
15 \\
1 \\
10 \\
149 \\
1.3 \\
275 \\
27 \\
3.3 \\
27\end{array}$ & $\begin{array}{c}10 \\
540 \\
30 \\
500 \\
18 \\
1 \\
33 \\
120 \\
1.8 \\
275 \\
19 \\
3.6 \\
77\end{array}$ & $\begin{array}{c}18 \\
710 \\
37 \\
500 \\
19 \\
7 \\
6 \\
151 \\
1.6 \\
360 \\
23 \\
3.3 \\
57\end{array}$ & $\begin{array}{c}8 \\
610 \\
16 \\
500 \\
25 \\
1 \\
4 \\
113 \\
2.2 \\
235 \\
18 \\
3.0 \\
61 .\end{array}$ & $\begin{array}{c}15 \\
610 \\
21 \\
130 \\
20 \\
8 \\
5 \\
134 \\
1.6 \\
310 \\
18 \\
3.7 \\
33\end{array}$ & $\begin{array}{c}8 \\
710 \\
37 \\
400 \\
20 \\
3 \\
4 \\
127 \\
0.9 \\
310 \\
16 \\
4.3 \\
23\end{array}$ & $\begin{array}{c}13 \\
600 \\
67 \\
400 \\
15 \\
1 \\
12 \\
75 \\
1.5 \\
490 \\
6 \\
4.2 \\
44\end{array}$ & $\begin{array}{c}17 \\
590 \\
169 \\
500 \\
19 \\
3 \\
3 \\
101 \\
1.9 \\
360 \\
13 \\
3.3 \\
37\end{array}$ & $\begin{array}{c}20 \\
700 \\
17 \\
600 \\
31 \\
1 \\
7 \\
104 \\
0.8 \\
570 \\
4 \\
1.0 \\
88\end{array}$ & $\begin{array}{c}75 \\
360 \\
40 \\
900 \\
22 \\
9 \\
5 \\
171 \\
2.2 \\
220 \\
10 \\
4.0 \\
23\end{array}$ & $\begin{array}{c}13 \\
550 \\
39 \\
600 \\
26 \\
2 \\
5 \\
161 \\
1.7 \\
370 \\
14 \\
2.7 \\
48\end{array}$ & $\begin{array}{c}11 \\
540 \\
18 \\
700 \\
24 \\
1 \\
9 \\
89 \\
1.6 \\
500 \\
3 \\
0.6 \\
140\end{array}$ & $\begin{array}{c}29 \\
560 \\
70 \\
500 \\
29 \\
4 \\
13 \\
118 \\
2.2 \\
405 \\
4 \\
1.8 \\
148\end{array}$ & $\begin{array}{c}10 \\
840 \\
52 \\
400 \\
14 \\
1 \\
2 \\
165 \\
1.9 \\
375 \\
13 \\
5.1 \\
28\end{array}$ & $\begin{array}{c}8 \\
670 \\
290 \\
700 \\
35 \\
1 \\
4 \\
122 \\
1.9 \\
390 \\
16 \\
2.9 \\
56\end{array}$ & $\begin{array}{c}11 \\
540 \\
3 \\
400 \\
35 \\
1 \\
6 \\
87 \\
1.3 \\
320 \\
14 \\
3.0 \\
50\end{array}$ & $\begin{array}{c}17 \\
245 \\
63 \\
500 \\
14 \\
52 \\
30 \\
233 \\
3.8 \\
80 \\
9 \\
4.7 \\
21\end{array}$ & $\begin{array}{c}7 \\
950 \\
60 \\
400 \\
38 \\
2 \\
7 \\
120 \\
4.4 \\
340 \\
14 \\
3.4 \\
112\end{array}$ \\
\hline
\end{tabular}

1 Major element analyses by atomic absorption spectrometry, Department of Geology, Acadia University. Analysts J. Cabilio and R. Yip Choy. Methods as described by Yip Choy (1982). Trace element analyses by CLIM Laboratory, Technical University of Nova Scotia; methods as described by Barr et a1. (1982).

2 Surface samples (WYR numbers) from locations shown on Figure 2. Drill core samples (WM numbers) from holes shown on Figure 2; depth in feet is indicated by number under hole number in table.

3 Symbol used on Figures $3,4,5$, and 6 .

* Total $\mathrm{Fe}$ expressed as $\mathrm{Fe}_{2} \mathrm{O}_{3}$. 
southeast of the pluton these dykes are intensively mineralized, containing abundant chalcopyrite (e.g. $0.33 \% \mathrm{Cu}$ over 12m; Black 1982).

Pegmatite and Related Rocks

Pegmatite, consisting essentially of coarse-grained quartz and potassium feldspar, was observed at several localities in the map area. Forms and dimensions of the bodies are not generally known, but one pegmatite in the northern end of the easternmost trench (Fig. 2) appears to be a dyke. It contains small yellow grains composed of leucoxene, probably replacing sphene.

To the north of the pluton, a body of albitized granite outcrops in a stream and was also encountered in drill hole WM-7 (Fig, 2) in the upper $25 \mathrm{~m}$. The rock consists of quartz and albite with interlocking texture. Scattered pale yellow grains of leucoxene (after sphene?) are also present. The areal extent of this unit and its relation to other granitoid rocks in the area are not known.

\section{Age}

A hornblende separate from granite porphyry sample WYR-24 (Fig. 2) was dated by the K-Ar method at Geochron Laboratories, Cambridge, Massachusetts. Although this sample is more mafic than most from the granite porphyry, its relatively high amphibole content made it most suitable for dating. It is also

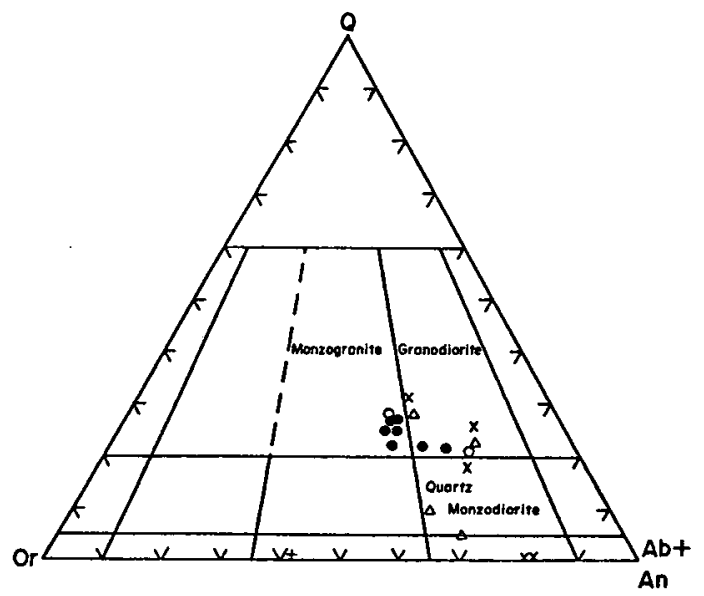

Fig. 3 - Normative orthoclase-quartz-albite+anorthite ternary diagram with field boundaries from Streckeisen (1976). Symbols are as indicated on Table l. one of the least altered samples, obtained from an outcrop well removed from the region of apparently maximum hydrothermal activity.

This sample gave an age of $402 \pm 20 \mathrm{Ma}$ (Table 2), placing the intrusion in the Early Devonian. This is not unreasonable considering the recent proliferation of Devonian and Carboniferous ages in northern Cape Breton Island (French 1984, Jamieson and Craw 1983).

\section{Geochemistry}

Major and trace element data for nineteen samples from the Whycocomagh Mountain pluton are presented in Table 1. As previously noted, analyzed samples from the granite porphyry (including two dykes) range from 60 to $68 \% \mathrm{SiO}_{2}$ with a cluster at $65-66 \%$ (Fig. 4). In contrast, samples from the granodiorite-diorite-endoskarn zone range from 53 to $63 \% \mathrm{SiO}_{2}$, overlapping the range of the granodiorite-monzodiorite dykes $\left(55-60 \%, \mathrm{SiO}_{2}\right)$. The suite of samples as a whole displays reasonably linear major element trends, with abundances of most major elements consistent with those in Cape Breton granitoid rocks in general (Fig. 4). Exceptions include $\mathrm{Fe}_{2} \mathrm{O}_{3}{ }^{\top}$ and $\mathrm{MnO}$, which follow a lower trend in the granodiorite-dioritemonzodiorite groups. This results in a shift towards the $\mathrm{MgO}$ corner on an AFM diagram (Fig. 5).

Trends displayed in Figure 4 cannot imply differentiation because the granodiorite-monzodiorite dykes at least are younger than the granite porphyry. It appears that the linear trends on these diagrams reflect the chemical coherency (either negative or positive) between $\mathrm{Si}$ and the other major elements, and do not indicate genetic relationships. The analyzed endoskarn contains low $\mathrm{Fe}_{2} \mathrm{O}_{3}{ }^{\top}$ and high $\mathrm{K}_{2} \mathrm{O}$, consistent with the abundance of diopside and $\mathrm{K}$ feldspar, respectively, but otherwise it lies within the trends of the suite as a whole.

Trace elements, especially $\mathrm{Ba}, \mathrm{Rb}$, $\mathrm{Sr}, \mathrm{Li}, \mathrm{Cu}, \mathrm{Mo}$, and $\mathrm{Zn}$, display wider scatter than the major elements, and linear trends are less obvious (Fig. 6). This is especialy true in the grano- 
diorite-diorite-monzodiorite groups. The data are suggestive of considerable redistribution by secondary processes. The two samples with highest $\mathrm{Cu}$ content are from a monzodiorite dyke in drill core from the main area of. mineralization and from a granite porphyry dyke $1500 \mathrm{~m}$ to the east. Other than some anomalously high $\mathrm{Mo}$ and $\mathrm{Ba}$ values, the main granite porphyry body does not display any obviously unusual chemical features.

\section{Petrologic Implications}

The Whycocomagh Mountain pluton is a calc-alkalic intrusion (Fig. 5). It displays many features of "I-type" granitoid rocks as defined by Chappell and White (1974), such as abundance of hornblende and sphene, occurrence of apatite only as inclusions in hornblende and other minerals, absence of muscovite, metaluminous character (molecular amount $\mathrm{Al}_{2} \mathrm{O}_{3}$ less than $\mathrm{CaO}+$ $\mathrm{Na}_{2} \mathrm{O}+\mathrm{K}_{2} \mathrm{O}$ ), and linear variation diagrams. This implies a meta-igneous crustal or mantle source. Metal dedeposits may be associated with such relatively dry intrusions if they rise to a high crustal level and encounter meteoric water (e.g. Strong 1981). A shallow level of emplacement of the Whycocomagh Mountain pluton is suggested by its porphyritic texture, zoned phenocrysts, and the presence of $\mathrm{K}$ feldspar with relatively low $2 \mathrm{~V}$ (transitional to high structural state).

The Whycocomagh Mountain pluton has many features in common with Gillis Mountain pluton in southeastern Cape Breton Island (Fig. 1), which is also of Devonian age, calc-alkalic, "Itype", and emplaced at a high crustal level (Barr and O'Beirne 1981). The Gillis Mountain pluton has been termed a porphyry-type $\mathrm{Cu}-\mathrm{Mo}$ pluton (Hollister et al. 1974; Kirkham and Soregaroli, 1975; Barr et al. 1982). The granite porphyry of Whycocomagh Mountain is chemically similar to the main porphyritic granite phase of the Gillis Mountain pluton, which contains between 65 and $70 \% \mathrm{SiO}_{2}$, and the range of compositions represented by the Whycoco- magh Mountain samples as a whole is similar to that of the monzodioriteporphyritic granite-granite suite of Gillis Mountain (Fig. 4,6). Some distinctive chemical features of Gillis Mountain are present to variable extent in the Whycocomagh Mountain data: high $\mathrm{U}$, Th and $\mathrm{Sr}$ and low B compared to other Cape Breton granitoid rocks, and wide spread in $\mathrm{Cu}, \mathrm{Mo}, \mathrm{Pb}, \mathrm{Zn}$, and $\mathrm{Ba}$ data (Fig. 6). However, the Gillis Mountain suite has much higher means and standard deviations for $\mathrm{Cu}, \mathrm{Pb}, \mathrm{Zn}$, and $\mathrm{Ba}$.

\section{GEORGE RIVER GROUP}

In the Whycocomagh Mountain area the George River Group consists predominantly of steeply dipping metasedimentary rocks, including schist, quartzite, and marble. In general, the schist occurs adjacent to the Whycocomagh Mountain pluton, followed outward by marble and then quartzite (Fig. 2). The actual stratigraphic sequence and structure are not known because of limited exposure. For the same reason, the relative effects of regional and contact metamorphism in these rocks are difficult to assess; only samples from drill core and trenches adjacent to the intrusion have been studied. However, the George River Group in this area is generally interpreted to have been regionally metamorphosed to Greenschist Facies (Keppie 1979) and, if so, many metamorphic features of the George River rocks around the Whycocomagh Mountain pluton are probably contact metamorphic (and metasomatic) in origin.

The schist in the vicinity of the Whycocomagh Mountain pluton is characterized by abundant mica (biotite and muscovite) which gives the rock a black to grey colour depending on the relative proportions of the two micas. Quartz and feldspar are the other major minerals. Garnet is present in some specimens. Local variants include siliceous hornfels and weakly foliated hornblende-biotite gneiss. 
The quartzite is fine-grained and sugary textured. Colour is usually grey, but locally pale brown.

The marble is white to grey, generally fine-grained and massive. Serpentine and chlorite, where present, give the rock a greenish colour. Pyroxene-garnet layers, ranging in width from a few centimetres to several metres, occur in marble north of the pluton. How-

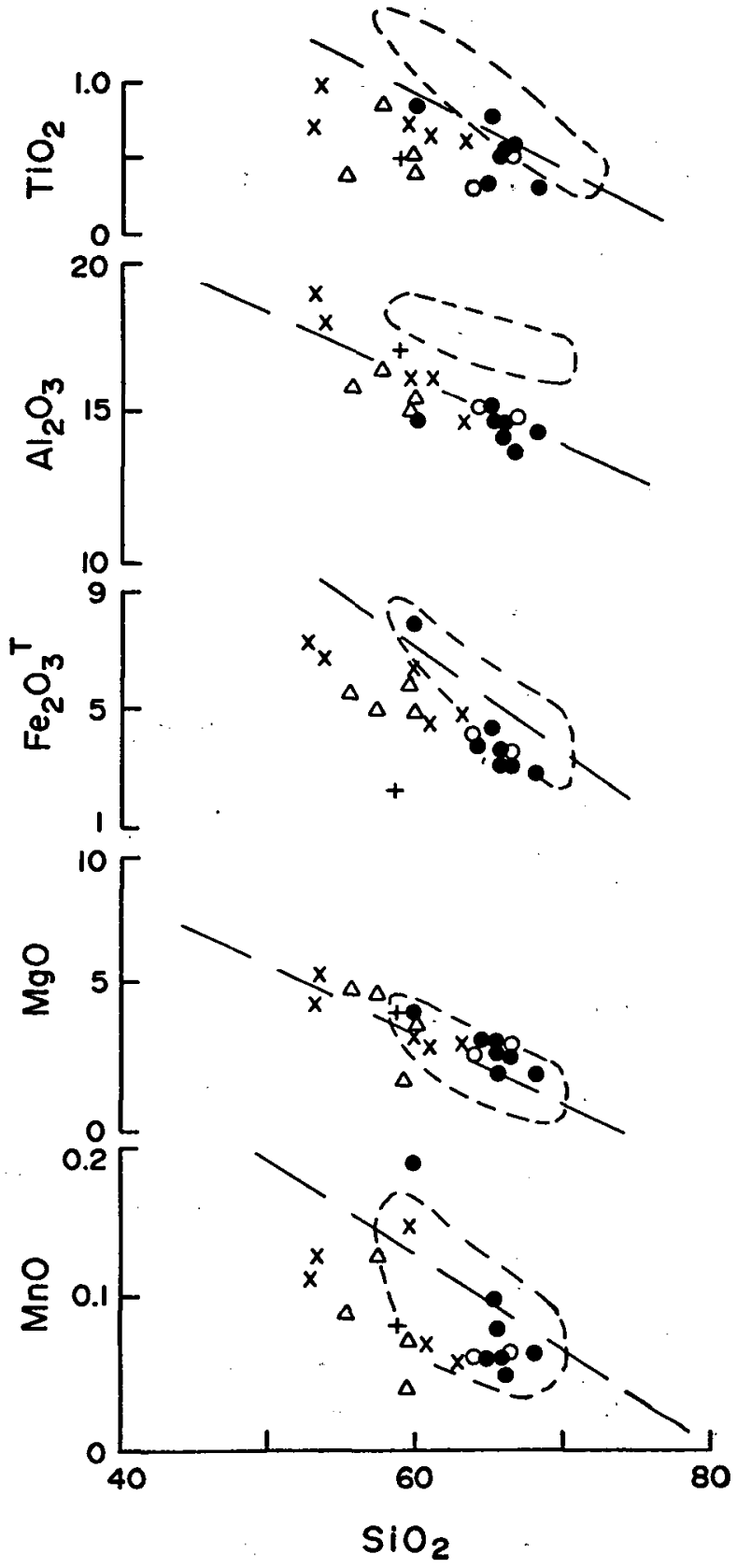

ever, the main area of skarn, with an average "width of 40 metres, is southeast of the pluton (Fig. 2), where it is the chief host for $\mathrm{Fe}-\mathrm{Cu}-\mathrm{W}-\mathrm{Mo}$ mineralization. the outcrop in this area is extremely poor; virtually all information has been obtained from drill core and several trenches across the skarn. The geology appears to be complex and only general lithologic cor-
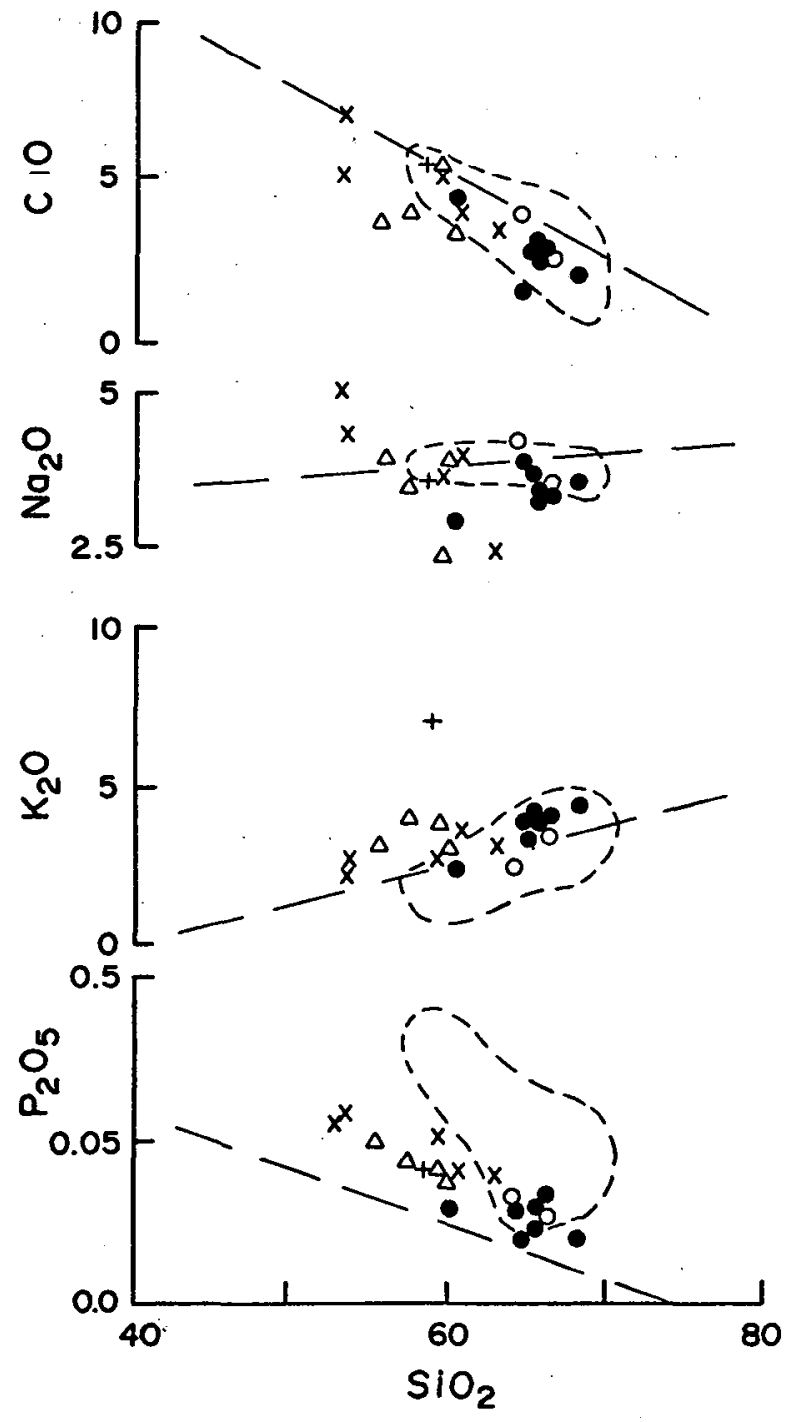

Fig. 4 - Silica variation diagrams for major element oxides in samples from the Whycocomagh Mountain pluton. Symbols as in Table l. Dashed lines are linear regression lines for selected Cape Breton granitoid plutons (from Barr et al. 1982). Dashed fields include analyzed samples from monzodiorite and granite of the Gillis Mountain pluton (Barr et al. 1982). 
relations among drill holes can be made as yet. Chatterjee $(1977,1980)$ and Chatterjee et al. (1980) have described the lithologies of the skarn in some detail, and our observations are in general agreement with those descriptions, as summarized below. The skarn consists of four distinct lithologies, one composed almost entirely of anhydrous silicates; the others composed mainly of hydrous silicates.

\section{Diopside-(andradite-forsterite) skarn}

Our sampling of this lithology produced only diopside-bearing specimens. However, the former presence of considerable olivine was indicated in one sample by the occurrence of serpentine and magnetite with characteristic replacement texture and Chatterjee (1980) described samples in which andradite and forsterite are abundant or dominant. The rock is very pale to medium green and consists of diopside with minor carbonate, quartz and sphene. Magnetite occurs in amounts up to $25 \%$. Although usually fine-grained $(0.2 \mathrm{~mm})$ the diopside in some samples is medium-grained $(2 \mathrm{~mm})$.

Microprobe analyses of diopside indicate two compositional ranges: $\mathrm{Di}_{9}{ }_{7} \mathrm{Hd}_{3}$

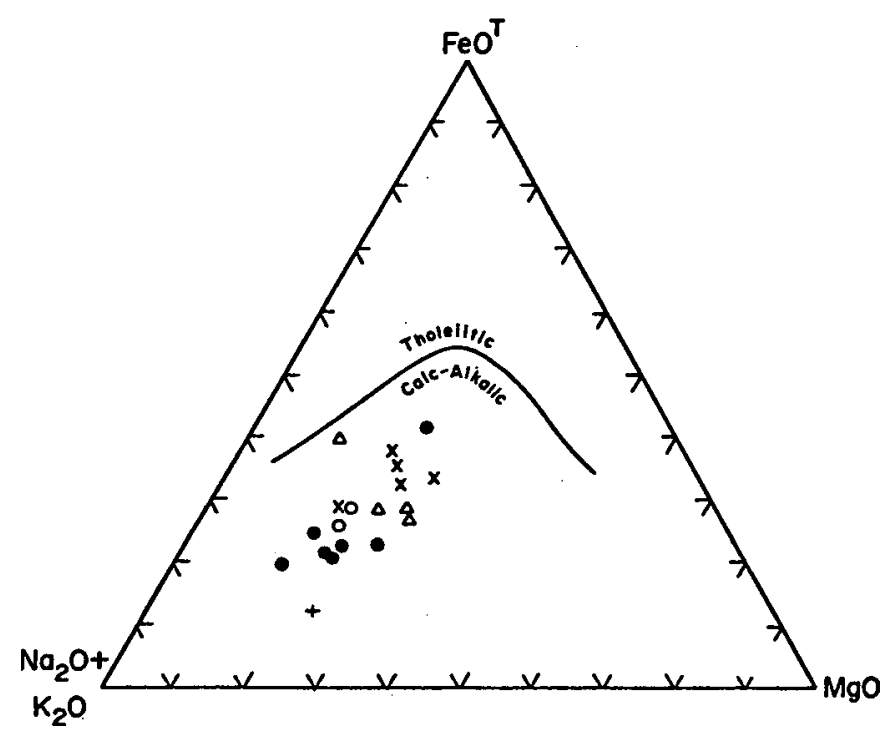

Fig. 5 - Ternary diagram of $\mathrm{Na}_{2} \mathrm{O}+\mathrm{K}_{2} \mathrm{O}-\mathrm{MgO}-\mathrm{FeO}^{\top}$ (Total $\mathrm{Fe}$ as $\mathrm{FeO}$ ). Symbols as in Table 1. Tholeiitic/ calc-alkalic dividing line from Irvine and Baragar (1971).
$\mathrm{Jo}_{0: 3}$ to $\mathrm{Di}_{86} \mathrm{Hd}_{13} \mathrm{JO}_{1}$, and $\mathrm{Di}_{0} \mathrm{Hd}_{28} \mathrm{JO}_{2}$ to $\mathrm{Di}_{6}{ }_{3} \mathrm{Hd}_{35} \mathrm{JO}_{2}$, with relatively constant conposition in any one sample.

\section{Tremolite Skarn}

The rocks of this lithology are medium-grained $(2-5 \mathrm{~mm})$, fibrous and dull greenish grey in colour. They consist mainly of tremolite (actinolite, in some samples) with subordinate calcite, diopside, quartz and magnetite.

Talc-chlorite-serpentine skarn

This lithology is always present adjacent to veinlets of sulphides. It consists of talc, chlorite and serpentine in varying amounts with minor tremolite, calcite, muscovite, quartz and sphene. Magnetite is a major constituent in some specimens together with minor pyrite, chalcopyrite and hematite. The rock is fine-grained to aphanitic and varies in colour from white to dark green depending on the amounts of chlorite and serpentine present. Microprobe analyses and optical determinations show that two types of chlorite are present: penninite, with characteristic anomalous blue interference colour, $\mathrm{Si}=6.3$ and $\mathrm{Fe} / \mathrm{Mg}+\mathrm{Fe}=$ 0.06 (average cation proportions); and pycnochlorite, with brown interference colour, $\mathrm{Si}=5.7$ and $\mathrm{Fe} / \mathrm{Mg}+\mathrm{Fe}=0.26$ (nomenclature of Deer et al. 1966).

\section{Tremolitic marble}

This lithology differs from the others in having a greater abundance of carbonate, as much as $50 \%$ or more. The remainder, in most samples we examined, is tremolite and talc, with minor quartz, chlorite and muscovite. In one specimen, however, diopside is the main silicate mineral. The rocks are grey or greenish grey and mediumgrained, and carbonate is apparent in hand specimen.

\section{Distribution of Skarn Lithologies}

It appears, from exposures in the trenches and from drill core, that the tremolitic marble is more common along the southern part of the skarn 

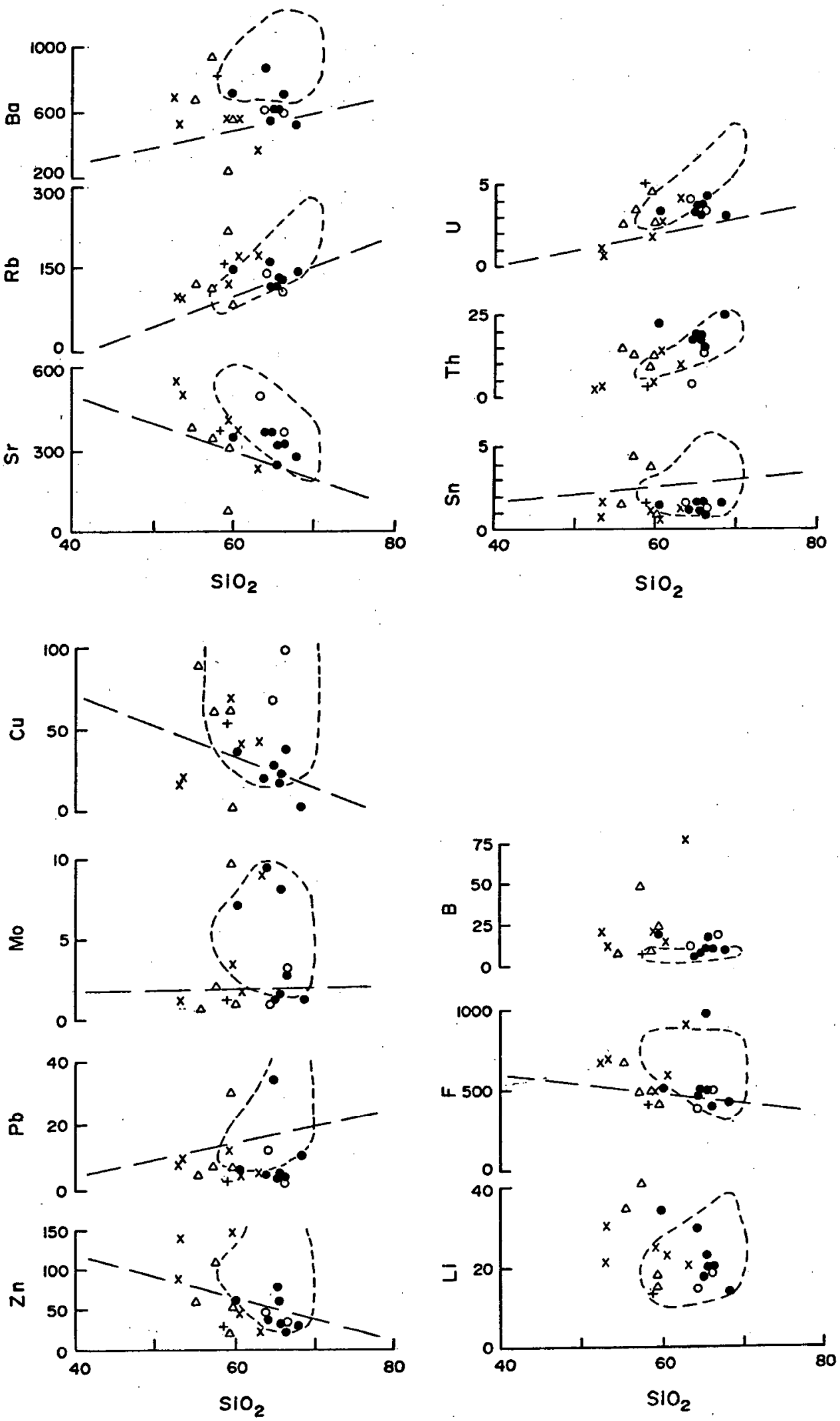

Fig. 6 - Silica variation diagrams for some trace elements in samples from the Whycocomagh Mountain pluton. Symbols as in Table 1. Dashed lines and fields as in Figure 4. Fields for $\mathrm{Cu}, \mathrm{Pb}$ and $\mathrm{Zn}$ in Gillis Mountain pluton exceed the scale of these plots. 
zone, with the dominantly silicate lithologies to the north, indicating differing original compositions or, more likely, less intensive skarn development to the south.

The relative distribution of the three dominantly silicate lithologies seems primarily related to the occurrence of mineralized fractures in the silicate skarn. As previously noted (Chatterjee 1980, Chatterjee et al. 1980), there is a bilateral progression towards such veins from diopside-andradite-fosterite skarn to the tremolite and finally the talc-chlorite-serpentine lithology, which can be interpreted as increasing intensity of hydrous alteration. This interpretation is supported by the occurrence of diopside relics in tremolite and pseudomorphs of serpentine after forsterite. The talc-chlorite-serpentine lithology also occurs away from the main skarn area, being typically found adjacent to mineralized fractures in the marble as well, in widths up to a metre or more.

\section{ECONOMIC GEOLOGY}

Exploration on the Whycocomagh $\mathrm{Fe}-$ $\mathrm{Cu}-\mathrm{W}$-Mo deposit, or prospect, as it is more correctly termed, has centered on the magnetite-bearing skarn with its associated chalcopyrite, scheelite and molybdenite, although recent drilling (Black 1982) has shown that mineralized fractures cut the hornfelsic and gneissic phases of the schist, the marble, and the quartzite and also occur in the plutonic rocks (especially in the marginal zone and granodioritemonzodiorite dykes). Unfortunately, no economic concentrations have yet been discovered in the area. The best copper intersection in recent drilling graded $2.7 \% \mathrm{Cu}$ over $1.5 \mathrm{~m}$ within a $10 \mathrm{~m}$ zone averaging less than 1\%; the best tungsten intersection was $0.35 \% \mathrm{WO}_{3}$ over Im (D. Black, pers. comm., 1982).

The minerals occur as veinlets in fractures and as disseminated grains in the alteration envelopes adjacent to the fractures. The ore mineral assemblage in the skarn is magnetite \pm chal- copyrite \pm pyrite \pm hematite \pm scheelite \pm molybdenite \pm pyrrhotite in approximate order of decreasing abundance. The average size of ore mineral grains is about $0.2 \mathrm{~mm}$ but individual grains range from $0.01 \mathrm{~mm}$ to several millimetres. Magnetite and scheelite occur in the anhydrous (diopside-andradite-fosterite) and hydrous (tremolite and talc-chlorite-serpentine) skarns whereas the sulphides and hematite are found only with the hydrous skarns. In one specimen, finely layered (millimetre scale) magnetite and iron-poor diopside $\left(\begin{array}{llll}\mathrm{Di}_{92.5} & \mathrm{Hd}_{75} & \mathrm{JO}_{0.5}\end{array}\right)$ with scattered scheelite are cut by "veins" of hydrous silicates with associated sulphides, suggesting a distinct earlier period for some of the magnetite-scheelite mineralization. The presence of two generations of scheelite is also supported by differences in composition reported by Chatterjee (1980), who found that the disseminated grains carry little molybdenum whereas larger (up to $8 \mathrm{~mm}$ ) plates along fractures contain up to 18.5 mole percent $\mathrm{CaMoO}_{4}{ }^{\circ}$

Chalcopyrite, pyrite, and hematite occur as individual grains or aggregates occupying interstices among euhedral hydrous silicates or as discontinuous veinlets. Pyrite in places exhibits euhedral faces and some grains contain abundant fine $(0.01 \mathrm{~mm})$ irregular magnetite. Molybdenite and pyrrhotite occur in disseminated grains and clusters, and were not observed in contact with the other ore minerals. Hence their paragenetic position is unknown except that they accompany hydrous silicates.

Late calcite veinlets with minor hematite cut all of the above assemblages.

\section{DISCUSSION}

Although the paragenetic sequence for the silicate and ore minerals has not been fully determined, the Whycocomagh deposit can be interpreted in terms of the genetic model for skarns presented by Einaudi et al. (1981). 
Table 2

K-Ar DATA FOR SAMPLE WYR $24^{\prime}$, WHYCOCOMAGH MOUNTAIN PLUTON

\begin{tabular}{|c|c|c|c|c|c|}
\hline$K \%$ & ${ }^{40} \mathrm{~K} \mathrm{ppm}$ & ${ }^{{ }^{0} \mathrm{Ar}} \mathrm{Apm}$ & ${ }^{40} \mathrm{Ar} * /{ }^{40} \mathrm{Ar}$ & ${ }^{40} \mathrm{Ar} * 1{ }^{40} \mathrm{~K}$ & Age (Ma) \\
\hline 0.392 & 0.478 & 0.01255 & 0.603 & 0.02624 & 402 \\
\hline
\end{tabular}

* Radiogenic ${ }^{40} \mathrm{Ar}$

1 Hornblende concentrate, $-80 /+100$ mesh, analyzed by Krueger Enterprises, Inc., Geochron Laboratories Division, Cambridge, Massachusetts. Constants used: $\lambda \beta=4.72 \times 10^{10} /$ year; $\lambda e=0.585 \times 10^{10} /$ year; ${ }^{40} \mathrm{~K} / \mathrm{K}=1.22 \times 10^{4} \mathrm{~g} / \mathrm{g}$.

Their model envisaged several stages in the evolution of skarns:

1. contact metamorphism accompanying emplacement of magma,

2. metasomatic skarn formation and initial ore deposition resulting from magmatic fluids evolved during magma crystallization, and

3. retrograde alteration and continued ore deposition by hydrothermal fluids during final cooling of the system.

They refer to the first two stages as "prograde", as they involve a spatial and temporal evolution of the skarn, even though temperature, after reaching a maximum, decreases during the metasomatic stage. Prograde skarn is characterized by anhydrous silicate minerals. The retrograde stage is characterized by the succession of increasingly hydrous silicate minerals and "destruction" of the skarn. This alteration (and accompanying ore mineral deposition) is usually controlled by fractures; it typically cuts across earlier skarn pattern and extends into other rock types including the intrusive body itself.

Proper assessment of the role of contact metamorphism and metasomatism in the development of the skarn at Whycocomagh would require knowledge of the grade of regional metamorphism and the original compositions of the rocks involved, but it seems reasonable to propose the addition of substantial amounts of $\mathrm{Si}$ and $\mathrm{Fe}$ and removal of $\mathrm{Ca}$ and $\mathrm{CO}_{2}$ during formation of prograde skarn, ${ }^{2}$ represented by the diopside-andradite-forsterite lithology.
The retrograde stage is well represented by the tremolite and talc-chlorite-serpentine lithologies. The tremolitic marble may have formed as a marginal phase during the prograde stage, especially where diopside is present, or during the retrograde stage.

The presence of magnetite and scheelite in anhydrous skarn indicates that some ore mineral deposition occurred during the prograde stage, as is common in other deposits (Einaudi et al. 1981) although the absence of ore minerals in some areas of diopsideandradite-forsterite skarn suggests an earlier period without metal deposition.

The sulphides and coarser scheelite are clearly related to the retrograde stage. Some magnetite, particularly where it is intergrown with pyrite formed during the retrograde stage. However, magnetite textures in the hydrous lithologies are generally similar to those in the anhydrous skarn and suggest that much of the magnetite was deposited during the prograde stage.

\section{CLASSIFICATION OF THE DEPOSIT}

The recent summary of diagnostic features of various types of skarn deposits by Einaudi et al. (1981) provides a basis for comparing the Whycocomagh deposit to others and for some assessment of its rotential.

The compcsitions of the garnet and pyroxene in the skarns, as well as the ore mineral assemblage, are consistent with those in copper skarns (Fig. 7) although those in oxidized tungsten skarns are similar. However, the small size, porphyritic texture, inferred shal- 

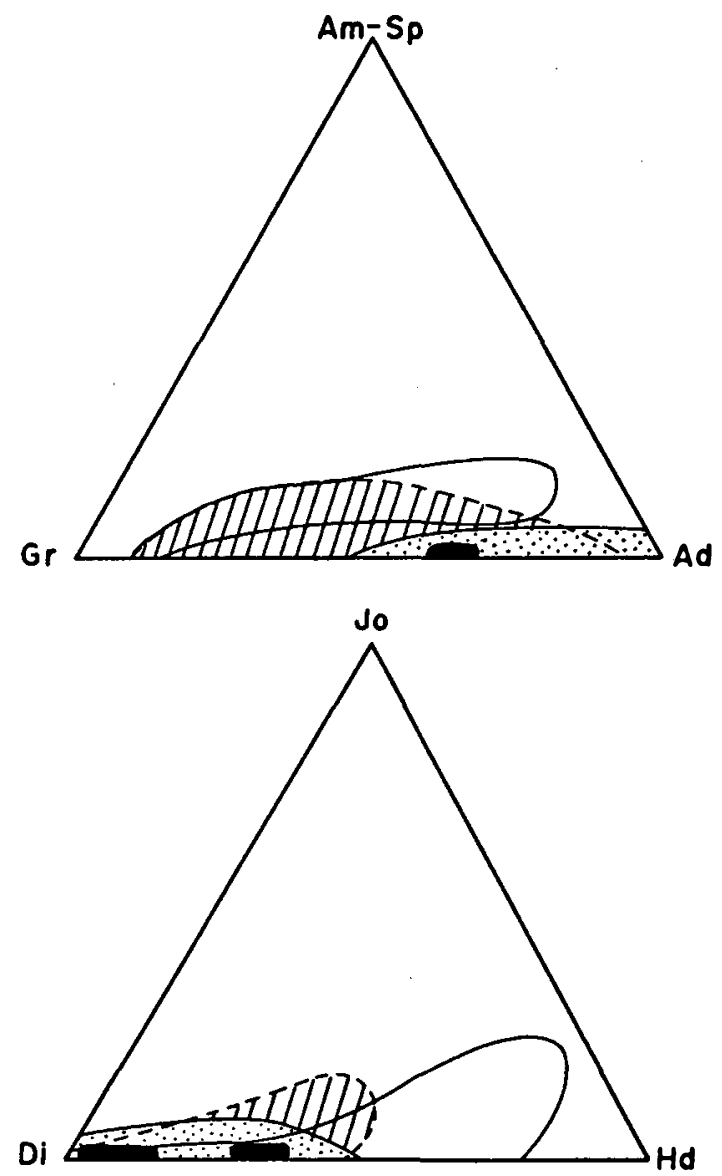

Fig. 7 - Grossularite-Almandine+Spessartine-Andradite and Diopside-Johannsenite-Hedenbergite ternary diagrams. Solid fields enclose range of garnet (upper diagram; data from Chatterjee 1980) and pyroxene compositions (this study) in samples from the Whycocomagh Mountain skarn. Fields for garnet and pyroxene compositions in reduced tungsten (open field), oxidized tungsten (hachured field) and copper (stippled field) skarns are from Einaudi et al. (1981).

low level of emplacement, and calcalkalic chemical affinity of the Whycocomagh Mountain pluton are typical of intrusions associated with copper skarns (Einaudi et al. 1981). Classification of the deposit as a copper skarn implies that it formed under lower temperature conditions than those most favourable for significant tungsten mineralization. Although to date this particular deposit appears to be subeconomic, the similarity of the Whycocomagh . Mountain pluton to the Gillis Mountain pluton, also Devonian and with significant associated mineralization, suggests that the recognition of Devonian granitoid intrusions is impor- tant for identifying exploration targets in Cape Breton Island, and that both the plutonic rocks and the country rocks are likely hosts for mineral deposition. Although it appears to be only weakly mineralized, the Whycocomagh Mountain pluton, like Gillis Mountain, has characteristics typical of plutons associated with porphyry-type $\mathrm{Cu}$-Mo deposits.

\section{ACKNOWLEDGEMENTS}

We are indebted to A. Hudgins and D. Black of M.E.X. Explorations Ltd. for access to drill core and unpublished reports and maps of the Whycocomagh Mountain property. Discussions with D. Black concerning the geology of the area were very helpful. We thank reviewers A.K. Chatterjee and R.V. Kirkham whose comments and suggestions led to a much improved manuscript. We also thank L. Cheslock and A. Edwards for typing and draughting. This project was largely funded by a grant from Gulf Minerals Canada Limited to S. Barr and J. Colwell. Additional funding was from operating grant A4230 to S. Barr from the Natural Sciences and Engineering Research Council of Canada.

BARR, S.M., and O'BEIRNE, A.M., 1981. Petrology of Gillis Mountain pluton, Cape Breton Island, Nova Scotia. Canadian Journal of Earth Sciences 18, pp. 395-404.

BARR, S.M., O'REILLY, G.A. and O'BEIRNE, A.M., 1982. Geology and geochemistry of selected granitoid plutons of Cape Breton Island. Nova Scotia Department of Mines and Energy Paper 82-1, 177p.

BLACK, D.L. 1978. Summary report on the first phase of exploration of the Whycocomagh Mountain tungsten prospect covering the period January-March 1978, M.E.X.-AMAX option, unpublished assessment report, M.E.X. Explorations Ltd.

----- 1982. M.E.X. Explorations Ltd. work report on the Whycocomagh Mountain property, unpublished assessment report, M.E.X. Explorations Ltd.

CHATTERJEE, A.K. 1977. Tungsten mineralization in the carbonate rocks of the George River Group, Cape Breton Island, Nova Scotia, Nova Scotia Department of Mines and Energy, Paper 77-7, 26p. 1980. Mineralization and associated wall rock alteration in the George River Group, Cape Breton Island, Nova Scotia, Ph. thesis, Dalhousie University.

CHATTERJEE, A.K., FORGERON, S., HUDGINS, A., ISENOR, G., MCNABB, B., MILLER, C., OLDALE, $H_{\text {. }}$ R., PATTERSON, J.M. and STEWART, E. 1980. Trip 6: Mineral deposits and mineralogenic provinces of 
Nova Scotia. Geological Association of Canada and Mineralogical Association of Canada Field Trip Guidebook, Halifax, 1980.

CHAPPELL, B.W., and WHITE, A.J.R. 1974. Two contrasting granite types. Pacific Geology 8, pp. 173174.

DEER, W.A., HOWIE, R.A. and ZUSSMAN, J. 1966. An Introduction to the Rock-forming Minerals. John Wiley and Sons, New York.

EINAUDI, M.T., MEINERT, L.D. and NEWBERRY, R.J. 1981. Skarn deposits. In Economic Geology, 75th Anniversary Volume, B.J. Skinner (ed.), pp.il 317-391.

FRENCH, V.A. 1984. Geology of Gillanders Mountain intrusive complex and satellite plutons, Lake Ainslie-Whycocomagh area, Cape Breton Island, Nova Scotia. Poster session at the Atlantic Geoscience Society Colloquium on Current Research in the Atlantic Provinces, Amherst, Nova Scotia, January 20,21 .

HAWTHORNE, F.C. 1983. The crystal chemistry of the amphiboles. Canadian Mineralogist 21, pp. 173480.

HOLLISTER, V.R., POTTER, R.R, and BARKER, A.L. 1974. Porphyry-type deposits of the Appalachian Orogen. Economic Geology 69, pp. 618-630.

HUTCHISON, C.S. 1973. Laboratory handbook of petrographic techniques. Wiley, New York, 527p.

IRVINE, T.N. and BARAGAR, W.R.A. 197l. A guide to the chemical classification of the common volcanic rocks. Canadian Journal of Earth Sciences 8, pp. 523-548.
JAMIESON, R.A. and CRAW, D. 1983. Reconnaissance mapping of the southern Cape Breton Highlands. In Current Research, Part A, Geological Survey of Canada Paper 83-1A, pp. 263-268.

KELLEY, D.G. 1967. Baddeck and Whycocomagh mapareas, Geological Survey of Canada Memoir 351, $65 p$.

KEPPIE, J.D. 1979. Geological map of the province of Nova Scotia, scale 1:500,000, Nova Scotia Department of Mies and Energy.

KIRKHAM, R.V. and SOREGAROLI, A.E. 1975. Preliminary asssessent of porphyry deposits in the Canadian Appalachians. Geological Survey of Canada Paper 75-1, Part A, pp. 249-252.

MILLIGAN, G.C. 1970. The geology of the George River Series, Cape Breton, Nova Scotia Department of Mines, Memoir 7, lllp.

SHELLEY, D. 1975. Manual of optical mineralogy. Elsevier, New York, 239p.

STRECKEISEN, A., 1976. To each plutonic rock its proper name. Earth Science Reviews 12, pp. 1-33.

STRONG, D. 1981. Ore deposit models-5. A model for granophile mineral deposits. Geoscience Canada, 8 , pp. 155-161.

YIP CHOY, R. 1982. Petrology of the Whycocomagh Mountain pluton, Cape Breton Island, Nova Scotia, B.Sc. Honours Thesis, Acadia University, 83p.

Reviewers: A.K. Chatterjee R.V. Kirkham 